\title{
Managing for rainfall variability: long-term profitability of different grazing strategies in a northern Australian tropical savanna
}

\author{
Peter O' Reagain ${ }^{\mathrm{A}, \mathrm{C}}$, John Bushell ${ }^{\mathrm{A}}$ and Bill Holmes ${ }^{\mathrm{B}}$ \\ ADepartment of Employment, Economic Development and Innovation, PO Box 976, Charters Towers, \\ Qld 4820, Australia. \\ ${ }^{B}$ Department of Employment, Economic Development and Innovation, PO Box 1085, Townsville, \\ Qld 4810, Australia. \\ CCorresponding author. Email: peter.o’reagain@deedi.qld.gov.au
}

\begin{abstract}
Several grazing strategies are recommended to manage sustainably for rainfall variability in northern Australia, but there is little objective data on their profitability relative to less sustainable management systems such as heavy stocking. In 1997, a large cattle grazing trial was initiated in northern Queensland to quantify the relative performance of a range of grazing strategies in a variable climate. These strategies were (i) moderate stocking (MSR) stocked at the calculated long-term carrying capacity (LTCC), (ii) heavy stocking (HSR) at twice LTCC, (iii) rotational wet-season spelling (R/Spell) at 1.5 LTCC, (iv) variable stocking (VAR), with stocking rates adjusted in May based on available forage and (v) a southern oscillation index (SOI)-variable strategy, with stocking rates adjusted in November based on available forage and SOI-based seasonal forecasts.

Rainfall varied over the 12-year trial period, with sequences of dry and wet years. Gross margins (GM) in the HSR were initially high but collapsed in drier years due to high costs and reduced product value. GMs only recovered in later years with a reduced stocking rate and increased rainfall. The VAR and SOI were also initially very profitable, but GMs plunged as rainfall declined due to reduced animal performance and the sale of poor-condition cattle. This sharp cut in stocking rates nevertheless allowed GMs to recover well in subsequent years. In the MSR, GMs remained relatively constant across most years due to low costs and a higher product value. The R/Spell also performed relatively well despite being compromised by an ill-timed fire, drought and the subsequent sale of poor-condition cattle.

Net present value (NPV) after 12 years was highest in the VAR ( $\$ 11962 / 100$ ha), followed by the MSR (\$11 873/100 ha), the SOI (\$11 167/100 ha) and the R/Spell (\$10 665/100 ha). NPV was by far the lowest in the HSR (\$6930/100 ha). Profitability also varied the most in the HSR, with a negative GM in 6 of the 12 years. Incorporating the costs of natural resource decline would further reinforce the case against heavy stocking. These results challenge the assumption that sustainable management in a variable environment is unprofitable.
\end{abstract}

Additional keywords: economic performance, pasture spelling, southern oscillation index, stocking rate, sustainability, variable stocking.

\section{Introduction}

Rainfall variability is a major management challenge to sustainability and profitability in many semiarid grazing systems. The extensive pastoral areas of northern Australia are no exception (Scanlan et al. 1994), with rainfall varying at annual, decadal and generational time scales (McKeon et al. 1998). In these environments, annual forage production can vary five to six fold or more, causing major fluctuations in short-term carrying capacity. Under these variable conditions, stocking rates based on 'average' rainfall could easily cause overgrazing, economic loss and resource degradation in a drought year. Historically, periodic droughts combined with unsustainable grazing management, particularly overstocking, have resulted in major episodes of economic loss and land degradation in Australia (McKeon et al. 2004). Climate change is likely to amplify the challenges of managing in a variable environment due to expected increases in drought intensity and frequency (McKeon et al. 2009).

Three main grazing strategies are commonly recommended to manage sustainably and profitably in these variable environments (Ash et al. 2000). First, 'conservative' or 'moderate stocking' aims to utilise some 'safe' amount of forage, usually 20-25\% of long-term average annual pasture growth (Johnston et al. 2000), to avoid overgrazing in most years and maintain land condition. Second, 'variable stocking' involves varying stocking rates with available forage to take advantage of wetter years but avoid overgrazing in dry years (Perry 1977; Wilson et al. 
1984; Pressland et al. 1988). In northern Australia, the obvious time to adjust stock numbers is at the end of the wet season in May or June (Ebersohn 1973). Seasonal climate forecasts such as the southern oscillation index might also be used proactively to guide stocking rate adjustments (McKeon et al. 1990; O'Reagain et al. 2003). Third, 'pasture spelling' or 'resting' may be used to buffer fodder shortages in poor years (Danckwerts et al. 1993; Muller et al. 2007) and may also ameliorate the effects of increased utilisation rates on pasture condition (Ash et al. 2001).

Despite major extension efforts by government agencies and community groups such as Landcare, there appears to have been only moderate adoption of these strategies. Assessments of land condition show significant areas of degradation (De Corte et al. 1991; Tothill and Gillies 1992; Karfs et al. 2009), indicating that unsustainable practices, such as overstocking and/or delaying destocking decisions until droughts are well advanced, continue. Aside from directly reducing the productivity of these grazing lands, these practices also increase soil erosion and runoff with obvious implications for water quality and downstream systems such as the Great Barrier Reef Lagoon (e.g. Furnas 2003).

Managers who overstock and/or only respond to droughts in a delayed, reactive fashion can also suffer significant financial losses through the costs of drought feeding, forced sale of poorcondition cattle and animal mortality. These losses can seriously affect long-term business performance, and ultimately jeopardise the survival of the enterprise (Hinton 1993; O'Meagher 2003).

The reasons for the non-adoption of more sustainable management practices such as lighter stocking are complex and the subject of ongoing investigations (e.g. Pannell et al. 2006). One major adoption constraint is the belief that 'sustainable' management is not profitable and that heavier stocking rates maximise economic returns (Stockwell et al. 1991; Lawrence et al. 1994), at least in the short to medium term.

Unfortunately, until fairly recently (Burrows et al. 2010), there has been little objective data available on the longer-term profitability and sustainability of recommended strategies relative to existing systems, such as constant heavy stocking. Previous grazing research in northern Australia largely focussed on introduced pastures (Eyles et al. 1985) or did not directly quantify the productivity or profitability of different grazing systems (e.g. McIvor and Gardner 1995; Ash et al. 2001). Importantly, most previous trials focussed on stocking rate per se (e.g. Gillard 1979; MacLeod and McIntyre 1997; Burrows et al. 2010) and not on managing for climate variability.

Case studies of managers successfully applying conservative stocking, variable stocking and/or rotational spelling (e.g. Mann 1993; Landsberg et al. 1998; Muller et al. 2007) are valuable but invariably confounded with the managers' circumstances and/or abilities (Briske et al. 2008). Linked biophysical and economic simulation models, such as GRASP and Enterprise, are also valuable (McKeon et al. 2000, 2004; Stafford-Smith et al. 2000); however, their effectiveness as a tool to facilitate adoption is limited. For land managers, it is the physical encounter, the power of 'seeing is believing' through research and demonstration (Nicholson et al.2003), that is the key element in adoption.

In summary, as noted by Stockwell et al. (1991), 'there are few hard data to convince graziers that the conventional wisdom that more cattle means more money is not necessarily correct', and many managers persist with conventional, less sustainable forms of management.

To address this problem a large cattle-grazing trial was initiated in 1997 in northern Queensland, Australia. Its specific objective was to quantify the relative ability of different grazing strategies to cope with climate variability in terms of their effects on animal production, economic performance and resource condition. A critical criterion for the work was that it be conducted at a scale and in a manner of direct relevance to the grazing industry.

The current paper presents 12 years of results on the economic performance of the different grazing strategies from this ongoing trial. It follows a previous paper detailing animal production in the different strategies (O'Reagain et al. 2009). Preliminary papers (O'Reagain et al. 2005; O'Reagain and Bushell 2008) and two reports (O'Reagain et al. 2008; O'Reagain 2009) on the effects of the strategies on pasture condition and runoff have also been published.

\section{Materials and methods}

The trial is located on 'Wambiana' $\left(20^{\circ} 34^{\prime} \mathrm{S}, 146^{\circ} 07^{\prime} \mathrm{E}\right)$, a commercial cattle property $\sim 70 \mathrm{~km}$ SW of Charters Towers, northern Queensland, Australia. Long-term (100 year) mean annual rainfall for 'Trafalgar', $17 \mathrm{~km} \mathrm{NW}$ of the study area is $643 \mathrm{~mm}(\mathrm{CV}=39 \%)$, with a historical range of 207-1409 mm. Most rain (70\%) falls in a relatively well defined wet season between December and March (Clewett et al. 2003). Mean maximum temperatures for January and July are $33.5^{\circ} \mathrm{C}$ and $24.4^{\circ} \mathrm{C}$ respectively. The vegetation, termed the AristidaBothriochloa pasture community (Tothill and Gillies 1992), is an open Eucalyptus savanna with smaller areas of Acacia harpophylla F.Muell. ex Benth. woodland, overlying tropical $\mathrm{C}_{4}$ grasses on relatively infertile kandosol, vertosol and sodosol soils (De Corte et al. 1991; Isbell 1996). Land and pasture condition of the site was moderate to very good (A or B condition; Chilcott et al. 2003) at the start of the trial in 1997 (O’Reagain 2009).

The experimental site is $1041 \mathrm{ha}$; there are 10 experimental paddocks of 93-117 ha in size, in a randomised block design, with two blocks of five treatments. To simulate paddocks on commercial properties, trial paddocks were laid out to contain a mixture of soil types (O'Reagain et al. 2009).

\section{Grazing strategies}

Five grazing strategies that are used by graziers in the district and/or are recommended to manage for climate variability (e.g. McKeon et al. 1993) were selected for testing. Importantly, all were practical management options for a region characterised by large paddocks and limited labour and infrastructure. Stocking rates were selected based on the limited available data (McIvor and Gardner 1995), local knowledge and the advice of the Wambiana trial Grazier Advisory Committee (O'Reagain et al. 2009). All stocking rates fell within the range used in the district.

Target stocking rates for each paddock in each grazing year ( $~ 1$ June to 31 May the following year) were set based on the expected mean weight of steers over the next 12 months, i.e. starting weight $+0.5 \times$ expected weight gain. Expected 

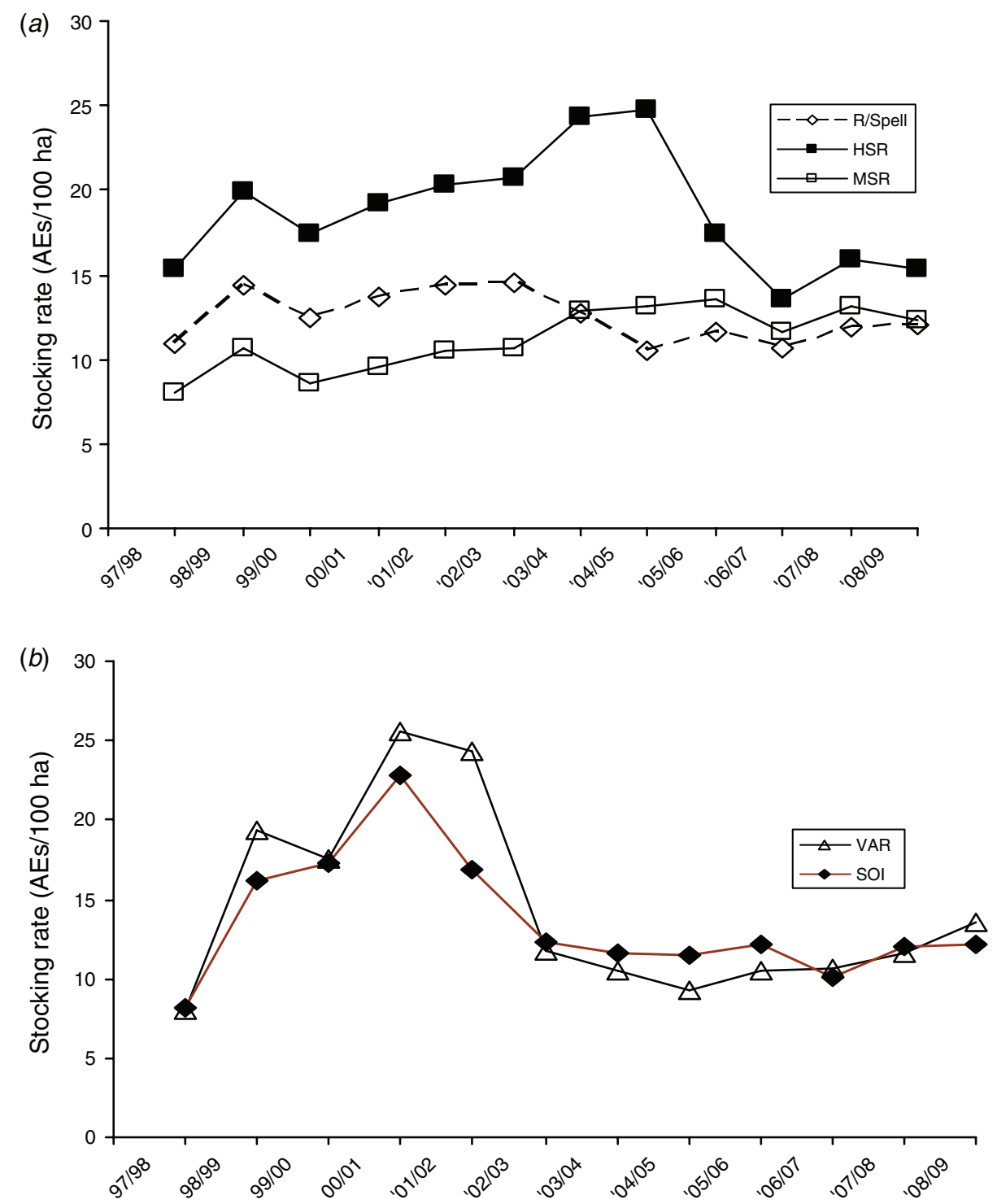

Fig. 1. Annual stocking rate expressed as animal equivalents (AEs) per 100 ha from 1997-98 to 2008-09 for (a) the heavy stocking rate (HSR), rotational spell (R/Spell) and moderate stocking rate (MSR) strategies and (b) the variable (VAR) and southern oscillation index-variable (SOI) strategies.

gain was assumed to be $100 \mathrm{~kg}$ in all years. In practice, the actual stocking rates achieved sometimes varied from the target rates because of differences between actual and expected weight gains and the practical difficulties of achieving exact stocking rates with large animals in relatively small paddocks.

The grazing strategies and their nominal stocking rates through the years of the trial are as follows [see O'Reagain et al. (2009) for more detail]:

(1) Moderate stocking rate (MSR) - moderate stocking (previously termed 'light' stocking by O'Reagain et al. 2009) at the estimated long-term carrying capacity (LTCC) of the site, i.e. $25 \%$ utilisation of the average long-term pasture production expected for the land types in question (e.g. McKeon et al. 2009). The MSR was initially stocked at $\sim 10$ ha per animal equivalent (AE, defined as a $450 \mathrm{~kg}$ steer) between 1997-1998 and 2000-2001, and at $\sim 8$ ha/AE thereafter (Fig. 1). This $20 \%$ increase in stocking rate in the MSR (as well as the HSR and R/Spell; see below) in May 2001 was implemented because the initial LTCC for the site appeared to have been underestimated and treatments appeared understocked.

(2) Heavy stocking rate (HSR) - heavy stocking at about twice the LTCC, i.e. $~ 50 \%$ utilisation of the average longterm pasture production. The HSR was stocked at $\sim 5 \mathrm{ha} / \mathrm{AE}$ between 1997-98 and 2000-01, and at $\sim 4$ ha/AE thereafter, as paddocks were considered to be understocked. In May 2005 , the stocking rate was cut to $\sim 6 \mathrm{ha} / \mathrm{AE}$ and maintained at this level until May 2009 because of the ongoing scarcity of forage in this treatment. 
(3) Variable stocking rate $(V A R)$ - stocking rates adjusted annually at the end of the wet season (May) based on pasture total standing dry matter (TSDM), as described by O'Reagain et al. (2009). Briefly, available forage was calculated from paddock TSDM, discounted for wastage and a minimum residue to prevent soil erosion. Stocking rate was calculated from the estimated daily dry matter intake per animal of $2 \%$ of expected average bodyweight and the number of days to the expected start of the wet season, as indicated from historical rainfall data (Clewett et al. 2003).

(4) Southern oscillation index (SOI) - variable strategy stocking rates adjusted annually in November as described above for the VAR, but based on available forage at the end of the dry season and SOI phase-based (Stone et al. 1996) climate forecasts for the next wet season (O'Reagain et al. 2009), on the Queensland Climate Change Centre of Excellence 'Long paddock' website (Anonymous 2008b). Initially, animal numbers were adjusted to a pre-set stocking rate based on broad classes of pasture TSDM and SOI values in November. However, from November 2002 onwards, stocking rates were set based on both the available forage for the rest of the dry season and the predicted wet season pasture growth expected in $75 \%$ of years with the prevailing SOI value (O'Reagain et al. 2009).

(5) Rotational spelling $(R /$ Spell $)$ - rotational wet season spelling applied in a three-paddock system, with a different paddock spelled annually. The R/Spell was stocked at $\sim 8 \mathrm{ha} / \mathrm{AE}$ between 1997-98 and 2000-01, and at $\sim 6 \mathrm{ha} / \mathrm{AE}$ up to November 2003 (O'Reagain et al. 2009). Thereafter, stocking rates were reduced to $\sim 8-9 \mathrm{ha} / \mathrm{AE}$ to allow recovery from the effects of drought and an ill-timed fire in November 2001 (O'Reagain et al. 2009).

\section{Fire management}

The trial site was burnt on 11 October 1999 to remove moribund grass and control woody species, and then wet-season spelled until 12 January 2000 to allow pasture recovery. Animals grazed together during this period on a nearby area, before returning to their respective treatment paddocks. The weight gains through this period were included in the economic analysis described below, but no cost was allocated to this grazing agistment.

\section{Experimental animals and animal husbandry}

Paddocks were stocked with 11-35 Brahman-cross steers to achieve the appropriate stocking rate in each treatment. Up until the end of 2000-01, steers were all about 2 years of age and were replaced annually at the end of each grazing year in late May. From May 2001 onwards, paddocks contained two similarsized groups of 2- and 3-year-old steers, with the older cohort being replaced annually by new, younger animals, i.e. animals remained on the trial for two full years. This change occurred to allow a longer period for treatment effects to emerge. Older, heavier animals could also be sent directly to the meatworks and carcass grades and values assessed (O'Reagain et al. 2009).

Animals were weighed and condition scored at the start and end of the grazing year (O'Reagain et al. 2009). Total annual liveweight gain (LWG) per paddock was calculated as the difference between the total fasted start- and end-weights of all animals in a paddock, standardised to 100 ha to facilitate strategy comparisons.

All husbandry actions were based on the advice of the Wambiana grazier advisory committee and were normal industry practice (Bortolussi et al. 2005a, 2005b). Cattle were initially unsupplemented but were given a commercial dry-season urea lick from May 2003, and wet season phosphorous from December 2004 onwards (Appendix 1). Starting in May 2005, steers were implanted annually with hormonal growth promotants (Compudose 400, Elanco Animal Health, Sydney, Australia). Animals were inoculated annually for botulism and against bovine ephemeral fever in 2007-08 and 2008-09.

Extra feeding had to be provided to animals with very poor body condition on three occasions. First, due to very low dryseason forage quality in November 2001, some poor-condition cattle (numbers in parentheses) in the SOI (20), VAR (6) and HSR (1) strategies had to be removed for $\sim 8$ weeks and fed a commercial weaner supplement to halt weight loss. Second, molasses and $8 \%$ urea (M8U) drought feeding had to be provided to the HSR in the late dry seasons of 2003-04, 2004-05, 2005-06 and 2006-07. On two or three occasions when animals were under extreme stress, a small amount of cottonseed meal was also provided with the M8U. Third, in November 2004, cattle had to be removed from one replicate of the HSR and fed with Chloris gayana hay and M8U for 10 weeks (O'Reagain et al. 2009) due to the complete absence of forage in these paddocks.

\section{Marketing}

From 1999 to May 2003, animals leaving the trial were sold locally or sent elsewhere. However, from May 2004 onwards, those leaving the trial, i.e. the older cohort, generally went directly to the meatworks, whereas lighter and/or poorer-condition animals were sold locally (O'Reagain et al. 2009). In May 2004, the \% in each strategy that went to the meatworks was: MSR (94\%), SOI and R/Spell (67\%), VAR (47\%) and HSR (5\%). In May $2005,75 \%$ of steers in the HSR went to the meatworks compared with $100 \%$ in the other four strategies. From 2006 onwards, all animals went to the meatworks.

\section{Value of beef produced}

Australian meatworks cattle are priced according to weight-forage, fat depth and butt shape (Anonymous 2008a). The beef produced per treatment, i.e. total LWG per annum, was valued based on the April or May 2004-09, and January 2010 price grids from the Townsville, Mackay and Rockhampton meatworks, the main destinations for district slaughter cattle. Based on animal production data (O'Reagain et al. 2009) and meatworks feedback sheets for the trial, the following two 'typical' carcass types for trial animals were selected: (1) good-condition steer - carcass weight of $>280 \mathrm{~kg}$, fat depth 7-22 mm, 0-6 teeth, average grid price $\$ 2.76 / \mathrm{kg}$ and (2) poorer-condition steer - carcass weight of $240-280 \mathrm{~kg}$, fat depth 3-22 mm, 0-6 teeth, average grid price $\$ 2.57 / \mathrm{kg}$. Based on a lower dressing percentage for lighter, poorer-condition steers $(50 \%$ v. $55 \%)$, these prices approximate to $\$ 1.50 / \mathrm{kg}$ and $\$ 1.30 / \mathrm{kg}$ liveweight for good and 
poorer-condition steers, respectively. Trial data also indicate a meatworks premium of about $\$ 0.20 / \mathrm{kg}$ liveweight for heavier, better-condition animals (O'Reagain et al. 2009).

At the start of the grazing year (1 June), animals were valued at $\$ 1.50 / \mathrm{kg}$ because of the premium that younger steers typically attract due to their growth potential. At the end of each grazing year (31 May), all animals in a treatment were valued at either $\$ 1.50 / \mathrm{kg}$ ('good-condition steer') or $\$ 1.30 / \mathrm{kg}$ ('poorcondition steer'), depending on condition score and weight gain, and after 2004, meatworks feedback sheets (Appendix 2). These values were used irrespective of whether animals had gone to the meatworks that year (older cohort) or whether they still had another year on the trial (younger cohort). Cattle removed in the late-dry season, as happened in the SOI strategy in November 2001 or the R/Spell in late 2003 (see below), were valued at $\$ 1.30 / \mathrm{kg}$ due to their poor condition.

\section{Variable and interest costs}

Variable costs were the actual supplement, vaccination and implant costs per strategy, adjusted to January 2010 prices at Charters Towers. Supplement prices (GST and transport inclusive; labour costs excluded) were molasses and urea $(\$ 0.26 / \mathrm{kg})$, cottonseed meal $(\$ 0.76 / \mathrm{kg})$, weaner supplement $(\$ 0.60 / \mathrm{kg})$, dry season urea lick $(\$ 0.81 / \mathrm{kg})$ and wet season lick $(\$ 1.21 / \mathrm{kg})$. Hay feeding in droughts is impractical on large cattle properties, so for the purposes of the present analysis, the current agistment cost for the district of \$2.75/ steer per week (M. Lyons, pers. comm., Wambiana Station, Charters Towers) was substituted for the costs of hay fed in the HSR in late 2004.

Interest costs on livestock capital were based on the total value of livestock in a paddock at the start of the season, i.e. Mass $_{\operatorname{In}} \times$ $\$ 1.50 / \mathrm{kg}$, using a real interest rate of $7.5 \%$. Real interest rates are used to calculate the opportunity cost of capital invested in livestock and to calculate the net present value, while prices and costs are in constant 2010 values. Real interest rate is the nominal rate less inflation.

\section{Economic analysis}

All costs and benefits were expressed in 2010 values. Treatments were compared using gross margins (GM) and net present value (NPV), which is the sum of discounted future benefits and costs.

\section{Gross margin and net present value analysis}

GMs per paddock were calculated as:

$$
\begin{aligned}
\mathrm{GM}= & \text { Mass }_{\mathrm{Out}} \times \text { value }- \text { variable costs }- \text { interest costs } \\
& - \text { Mass }_{\mathrm{In}} \times \text { value },
\end{aligned}
$$

where Mass In and Mass Out are the total mass of all animals in a paddock at the start and end of a grazing year, respectively, value is price of beef in $\$ / \mathrm{kg}$, variable costs are all supplement and inoculation costs and interest costs reflect interest on livestock capital calculated at $7.5 \%$.

Accumulated GM (AGM) was calculated as the sum of paddock GMs for successive years, compounded annually at a rate of $7.5 \%$.
Net present value (NPV) for each strategy after 12 years was computed as:

$$
\mathrm{NPV}=\sum_{t=0}^{t} \frac{(B t-C t)}{(1+r)^{t}},
$$

where $B$ denotes the dollar benefits received in any year, $C$ refers to the costs incurred in any year, $r$ is the discount rate and where $t$ refers to the year (Sinden and Thampapillai 1995).

Annualised NPV (ANPV) was calculated as follows:

$$
\mathrm{ANPV}=\mathrm{NPV} \times\left[r \times(1+r)^{t}\right] /\left[(1+r)^{t}-1\right]
$$

where $r$ is the discount rate and $t$ is the period in years (Chisholm and Dillon 1966).

NPV was calculated from annual GMs by using a $7.5 \%$ interest rate. A sensitivity analysis was also conducted at rates either side of this, using, in each instance, the same interest on livestock capital and in the NPV calculation. In the present NPV analysis, AGMs serve as a proxy for cash flow. In using the GM rather than the purchase and sale transactions, this NPV calculation misses the capital tied up in stock purchase. To account for this, NPV is calculated on GM (less interest paid on livestock capital). The alternative, but more complex, method would be to calculate NPV on monthly cash flows but for simplicity, we pick up the cost of livestock capital flows by working on annual GMs, as defined previously.

\section{Marginal analysis of increasing stocking rates}

Marginal analysis was used to determine if it was profitable to increase stocking rates from 'moderate' to 'high' by setting the extra GM against the extra stock (and thus extra capital) in the high stocking rate. Marginal analysis of the extra financial return from HSR relative to MSR was conducted across all years as follows: the increase in GM after interest for the HSR versus the MSR was calculated as the value of beef produced less variable costs from HSR, less the same calculation from MSR. The extra GM was then divided by the additional adult equivalents in the HSR relative to the MSR to give the marginal return per AE from the increased stocking rate.

\section{Sensitivity analysis}

A sensitivity analysis of the effects of different interest rates on livestock capital- and condition-based price premiums for marketed cattle was conducted on the marginal returns of running extra AEs in the HSR relative to the MSR. The default interest rate was $7.5 \%$, and rates of 0 and $15 \%$ were also considered for comparison (Fig. 2). Simulations were run for a range of scenarios involving all combinations of interest rate $(0 \%, 7.5 \%$ and $15 \%)$ and price premium $(0-\$ 0.30 / \mathrm{kg})$. Results for different scenarios are presented as the margin per AE averaged across all years, as well as separately for wet (1997-98 to 2001-02, 2007-08 and 2008-09) and dry years (2002-03 to 2006-07).

\section{Statistical analysis}

Statistical analyses were undertaken using the GENSTAT 9 statistical package (VSN International Ltd, Hemel Hempstead, 
UK). The effect of grazing strategy on GM, variable costs and livestock interest costs was analysed separately for each year using an analysis of variance. The experimental unit was the 'paddock', i.e. there were two replications for each strategy. Normality assumptions were assessed using standardised normal plots of residuals. Pair-wise comparisons between strategies were made using protected least-squares significant differences.

\section{Results}

\section{Rainfall}

Rainfall was generally above average and well distributed over the first 4 years of the trial (Fig. 3). Thereafter, rainfall declined, with the years between 2001-02 and 2006-07 amongst the lowest $20-30 \%$ of rainfall years on record (Clewett et al. 2003). With the exception of 2005-06, rainfall in these years was also poorly distributed. Rainfall in 2007-08 (1116 mm) and 2008-09 $(1030 \mathrm{~mm})$ was exceptional, with these years being the 4 th and 5th wettest respectively on record (Clewett et al. 2003).

\section{Stocking rates}

The initial high stocking rates (4-5 ha/AE) in the HSR could only be maintained until May 2005 (Fig. 1) when they had to be cut by $30 \%$ due to ongoing forage deficits, the repeated need for dry season drought feeding and an obvious decline in carrying capacity. In contrast, MSR stocking rates remained relatively constant, with adequate forage available in all years. In the $\mathrm{R} /$ Spell, the initial moderate stocking rate ( $6 \mathrm{ha} / \mathrm{AE})$ had to be reduced in April 2003 due to the after-effects of an ill-timed fire in October 2001 and poor follow-up rains (O'Reagain et al. 2009).

VAR stocking rates started at moderate levels in 1997-98, but thereafter were increased rapidly to very high levels ( $\sim 4 \mathrm{ha} / \mathrm{AE})$ to take advantage of the high pasture TSDM (3000-5000 kg/ha). Stocking rates in the VAR were halved in May 2002 in response
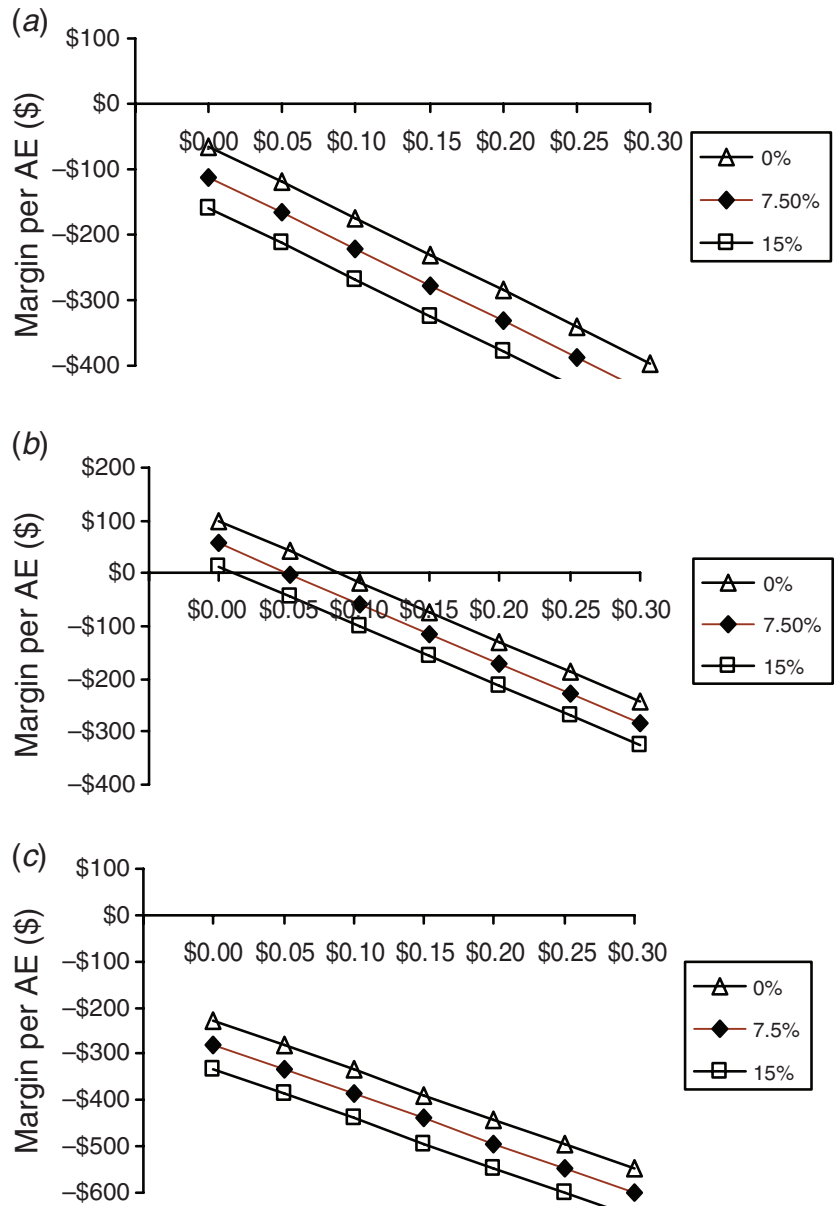

Price differential $(\$ / \mathrm{kg})$

Fig. 2. Marginal return per extra animal equivalent (AE) per 100 ha for heavy $v$. moderate stocking over different interest rate and product price scenarios for $(a)$ all, $(b)$ wet and $(c)$ dry years.

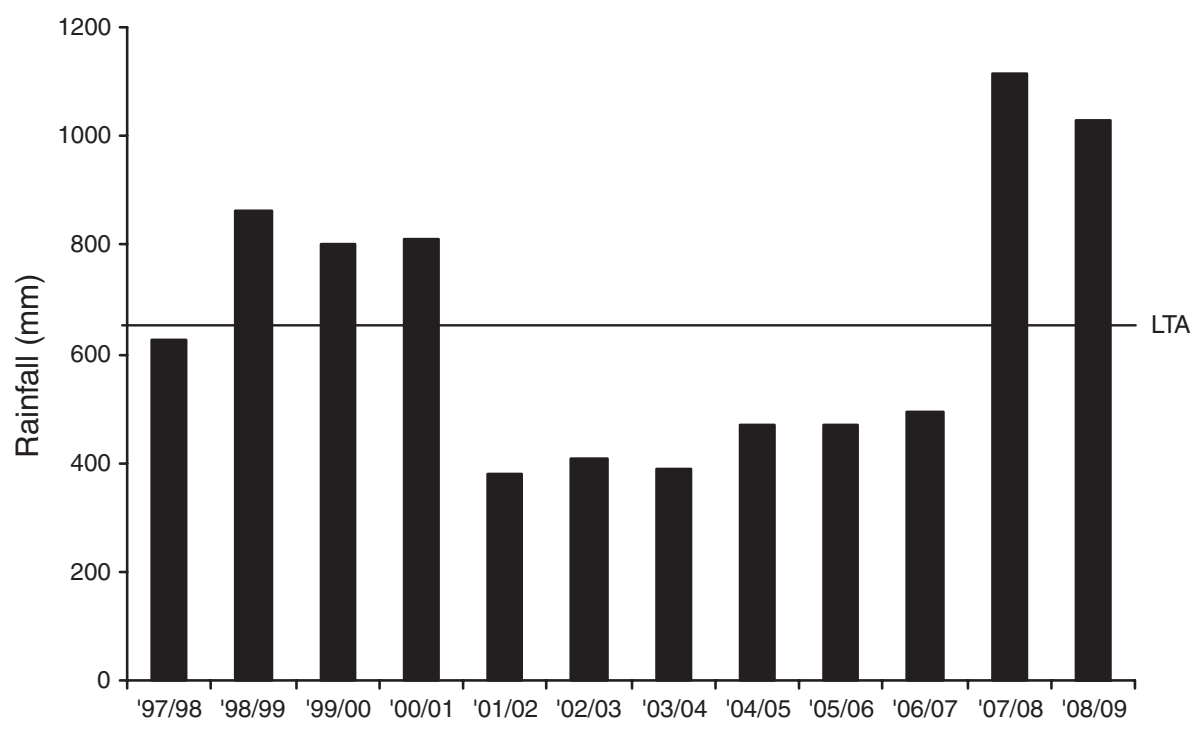

Fig. 3. Annual rainfall (July-June) from 1997-98 to 2008-09 at the Wambiana grazing trail and long-term average rainfall (LTA) for the area. 
to the sharp drop in TSDM, and then progressively reduced below those in the MSR (O'Reagain et al. 2009). SOI stocking rates were also initially increased to high levels in early years, due to the high pasture TSDM and positive SOI outlooks (Anonymous 2008b). Stocking rates were then cut in October 2001 due to declining TSDM and the negative/neutral SOI, i.e. use of the SOI resulted in stocking rates being cut 6 months earlier than in the VAR. Stocking rates in both the VAR and SOI gradually increased again after 2006-07 as rainfall and pasture yields improved (Fig. 1).

\section{Gross margins of different grazing strategies}

Annual GMs varied widely from between $\$ 2000 / 100$ ha and $\$ 4700 / 100$ ha in the best rainfall years (2000-01) to losses in some strategies of more than $-\$ 1000 / 100$ ha in the driest years (Fig. 4). Margins in 2006-07 were also very low due to the short wet season, but rebounded in 2007-08 and 2008-09 with the good, well distributed rainfall.

The grazing strategy applied significantly $(P<0.05)$ affected GM in 8 of the 12 years (Table 1). In the earlier, wetter years (1997-2001), heavily stocked strategies such as the HSR, VAR and SOI had substantially higher GMs than did the R/Spell or MSR. This was particularly marked $(P<0.05)$ in $1999-00$ and 2000-01, with e.g. the HSR earning from $\$ 1400 / 100$ ha to $\$ 1900 / 100$ ha more per annum than the MSR. However, with the onset of the dry years in 2001-02, GMs in these heavierstocked strategies plummeted to a net loss of about $-\$ 1000$ / 100 ha. In contrast, the decline was relatively minor in the R/Spell and MSR (Fig. 4), with positive GMs maintained. Thereafter, the MSR consistently delivered GMs as good as or far better (2003/04) than the other strategies.

GMs in the SOI and VAR strategies recovered strongly in 2002-03 in response to reduced stocking rates, and improved thereafter to approach those in the MSR. Conversely, maintenance of high stocking rates in the HSR gave a consistently negative GM between 2001-02 and 2006-07. This effect persisted despite the reduction in HSR stocking rates in 2005. Nevertheless, with good rainfall, the GM in the HSR (stocked at the reduced rate) rebounded sharply and was the highest of all strategies in 2007-2008 and the second highest in 2008-09 (Fig. 4). In the R/Spell, GMs in the dry years were initially relatively high, but complications arising from the 2001 fire precipitated a temporary drop in GM due to the forced sale of relatively poor-condition animals in November 2003.

In summary, at an assumed interest rate of $7.5 \%$, the HSR had a negative GM in 6 of 12 years, with the other strategies negative in only 1 (MSR \& R/Spell) or 2 (VAR \& SOI) of 12 years (Table 1). The magnitude of this loss varied widely among the latter group, however, with the losses in the VAR (-\$1648/ $100 \mathrm{ha})$ and SOI (-\$1448/100 ha) in 2001-02 being far higher than those in the R/Spell ( $-\$ 255 / 100$ ha) in 2002-03 or those in the MSR (-\$58/100 ha) in 2006-07.

\section{Accumulated gross margin}

In the earlier wetter years, AGM increased rapidly in the heavierstocked strategies, with the HSR, for example, having an AGM nearly $\$ 4500 / 100$ ha greater than the MSR by 2000-01 (Fig. 5). Thereafter however, AGM steadily declined in the HSR as the strategy ran at a consistent loss through the dry years. In contrast, in the VAR and SOI, after an initial loss in the first dry year, the reduced stocking rate allowed AGM to recover and continue to grow thereafter in both strategies (Fig. 5). In the MSR and R/Spell, AGM grew steadily and by 2003-04 both strategies equalled, and then exceeded, the HSR. After 12 years, AGM was highest in the MSR (\$28 279/100 ha) and VAR (\$28 490/100 ha) and lowest in the HSR (\$16 505/100 ha). AGMs in the SOI (\$26596/100ha) and R/Spell (\$25 402/100ha) were somewhat $(\sim 2500)$ lower than those in the MSR and VAR, but still far ahead of the HSR (Fig. 5).

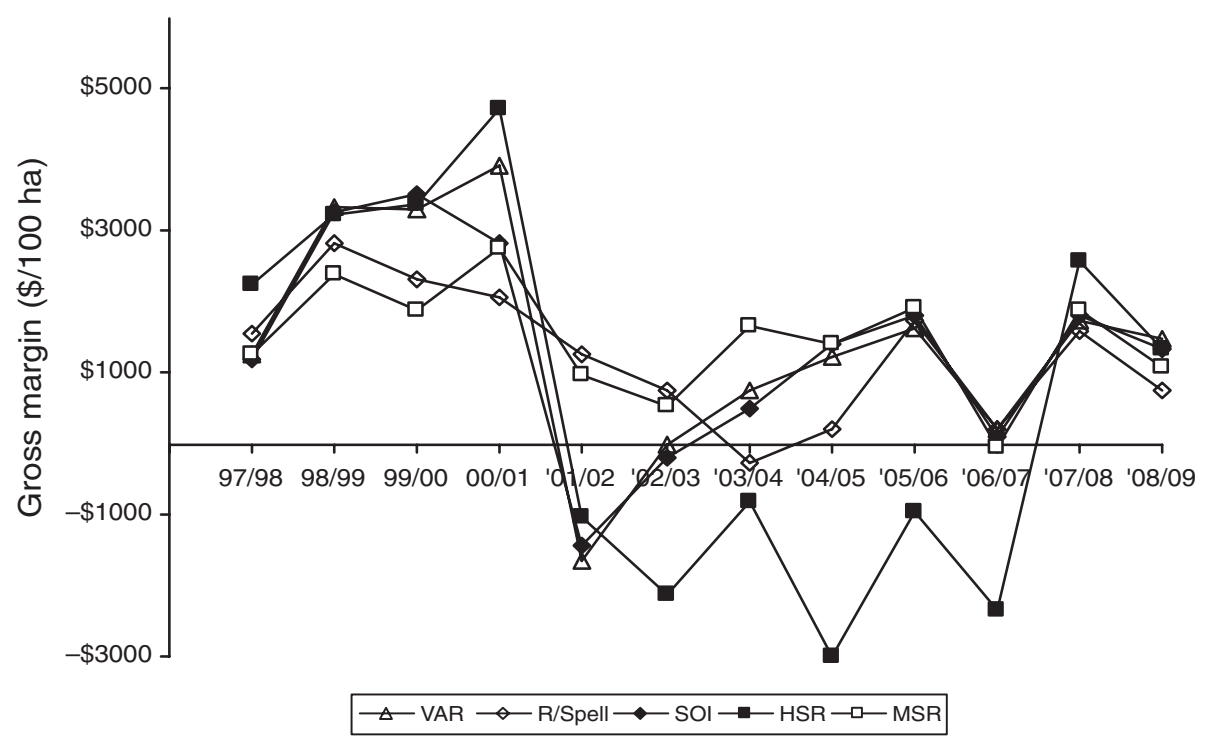

Fig. 4. Gross margin (\$) per 100 ha from $1997-98$ to $2008-09$, using an interest rate of $7.5 \%$ and a conditionbased price premium for the variable (VAR), rotational spell (R/Spell), southern oscillation index-variable (SOI), heavy stocking rate (HSR) and moderate stocking rate (MSR) strategies. See text for details. 
Table 1. Mean gross margin, variable costs and interest on livestock capital for five grazing strategies at the Wambiana grazing trial $F$-probabilities are for overall treatments differences in the same year. HSR, heavy stocking rate; MSR, moderate stocking rate; R/Spell, rotational spelling; SED, standard error of a difference within a year; SOI, southern oscillation index-variable; VAR, variable. Within a year, means for the same variable with the same letter do not differ significantly at $P=0.05$. Significant values are in italic

\begin{tabular}{|c|c|c|c|c|c|c|c|c|c|c|c|c|}
\hline \multirow{2}{*}{$\begin{array}{l}\text { Grazing } \\
\text { strategy }\end{array}$} & \multicolumn{12}{|c|}{ Year } \\
\hline & $1997-98^{\mathrm{A}}$ & 1998-99 & $1999-2000^{\mathrm{B}}$ & $2000-01$ & $2001-02$ & $2002-03$ & $2003-04$ & 2004-05 & 2005-06 & 2006-07 & 2007-08 & 2008-09 \\
\hline \multicolumn{13}{|c|}{ Net gross margin $(\$ / 100 \mathrm{ha})$} \\
\hline VAR & 1260 & 3333 & $3291 \mathrm{a}$ & $3922 b$ & $-1648 b$ & $-27 b$ & 761 & 1217 & $1643 a$ & $191 \mathrm{a}$ & 1724 & $1468 \mathrm{a}$ \\
\hline SOI & 1174 & 3281 & $3520 \mathrm{a}$ & $2832 c$ & $-1448 b$ & $-206 b$ & 486 & 1393 & $1804 \mathrm{a}$ & $89 \mathrm{a}$ & 1796 & $1323 a$ \\
\hline HSR & 2233 & 3237 & $3365 \mathrm{a}$ & $4718 \mathrm{a}$ & $-1037 b$ & $-2110 \mathrm{c}$ & -803 & -3035 & $-960 \mathrm{~b}$ & $-2348 b$ & 2584 & $1331 \mathrm{a}$ \\
\hline MSR & 1262 & 2393 & $1878 b$ & $2744 \mathrm{~cd}$ & $959 a$ & $522 \mathrm{a}$ & 1647 & 1421 & $1909 a$ & $-58 \mathrm{a}$ & 1871 & $1080 \mathrm{~b}$ \\
\hline \multicolumn{13}{|c|}{ Variable costs $(\$ / 100 \mathrm{ha})$} \\
\hline VAR & $12 \mathrm{c}$ & $22 \mathrm{a}$ & $24 \mathrm{a}$ & $31 \mathrm{a}$ & $172 b$ & 1100 & $444 c$ & $448 b$ & $201 \mathrm{c}$ & $274 b$ & 170 & $369 a$ \\
\hline $\mathrm{R} /$ Spell & $16 \mathrm{~b}$ & $16 \mathrm{~b}$ & $17 \mathrm{~b}$ & $17 \mathrm{c}$ & $17 \mathrm{~b}$ & 1304 & $607 \mathrm{bc}$ & $417 \mathrm{~b}$ & $195 \mathrm{c}$ & $200 \mathrm{~b}$ & 148 & $292 b$ \\
\hline SOI & $12 \mathrm{c}$ & $22 \mathrm{a}$ & $24 a$ & $30 \mathrm{a}$ & $488 \mathrm{a}$ & 1072 & $443 c$ & $499 b$ & $227 b c$ & $205 b$ & 187 & $343 a$ \\
\hline HSR & $23 a$ & $23 a$ & $24 \mathrm{a}$ & $24 \mathrm{~b}$ & $50 \mathrm{~b}$ & 1405 & $1182 \mathrm{a}$ & $3189 a$ & $1582 \mathrm{a}$ & $682 a$ & 218 & $380 \mathrm{a}$ \\
\hline VAR & $297 \mathrm{c}$ & $771 \mathrm{a}$ & $698 \mathrm{a}$ & $821 \mathrm{a}$ & $1201 \mathrm{a}$ & $509 \mathrm{bc}$ & $459 \mathrm{~b}$ & $380 \mathrm{~d}$ & $440 \mathrm{c}$ & 469 & $522 \mathrm{~b}$ & $615 b$ \\
\hline R/Spell & $414 b$ & $547 \mathrm{~b}$ & $492 b$ & $447 \mathrm{c}$ & $657 \mathrm{~cd}$ & $610 \mathrm{~b}$ & $538 \mathrm{~b}$ & $435 \mathrm{c}$ & $500 \mathrm{bc}$ & 482 & $522 \mathrm{~b}$ & $558 \mathrm{~b}$ \\
\hline SOI & $304 c$ & $578 \mathrm{~b}$ & $674 a$ & $744 a$ & $806 \mathrm{bc}$ & $535 \mathrm{bc}$ & $471 b$ & $451 \mathrm{c}$ & $498 \mathrm{bc}$ & 441 & $526 \mathrm{~b}$ & $559 \mathrm{~b}$ \\
\hline HSR & $575 \mathrm{a}$ & $795 a$ & $691 \mathrm{a}$ & $636 \mathrm{~b}$ & $1012 \mathrm{ab}$ & $938 \mathrm{a}$ & $1006 \mathrm{a}$ & $1110 \mathrm{a}$ & $730 \mathrm{a}$ & 658 & $685 \mathrm{a}$ & $742 a$ \\
\hline MSR & $299 \mathrm{c}$ & $395 \mathrm{c}$ & $329 \mathrm{c}$ & 306d & $482 d$ & $445 c$ & $507 b$ & $556 \mathrm{~b}$ & $560 \mathrm{~b}$ & 508 & $567 \mathrm{~b}$ & $591 \mathrm{~b}$ \\
\hline$F$-value & $<0.001$ & 0.003 & 0.002 & $<0.001$ & 0.010 & 0.002 & $<0.001$ & $<0.001$ & 0.005 & 0.160 & 0.023 & 0.038 \\
\hline SED & 15.86 & 43.3 & 39.9 & 33.2 & 101.4 & 44.5 & 40.0 & 17.17 & 32.8 & 70.4 & 31.4 & 39.0 \\
\hline
\end{tabular}

${ }^{\text {A }}$ Based on 6 months of data from 19 December 2007 to June 1998.

${ }^{B}$ In 1999-2000, all animals were agisted together for 15 weeks after the trial was burnt - see text for details.

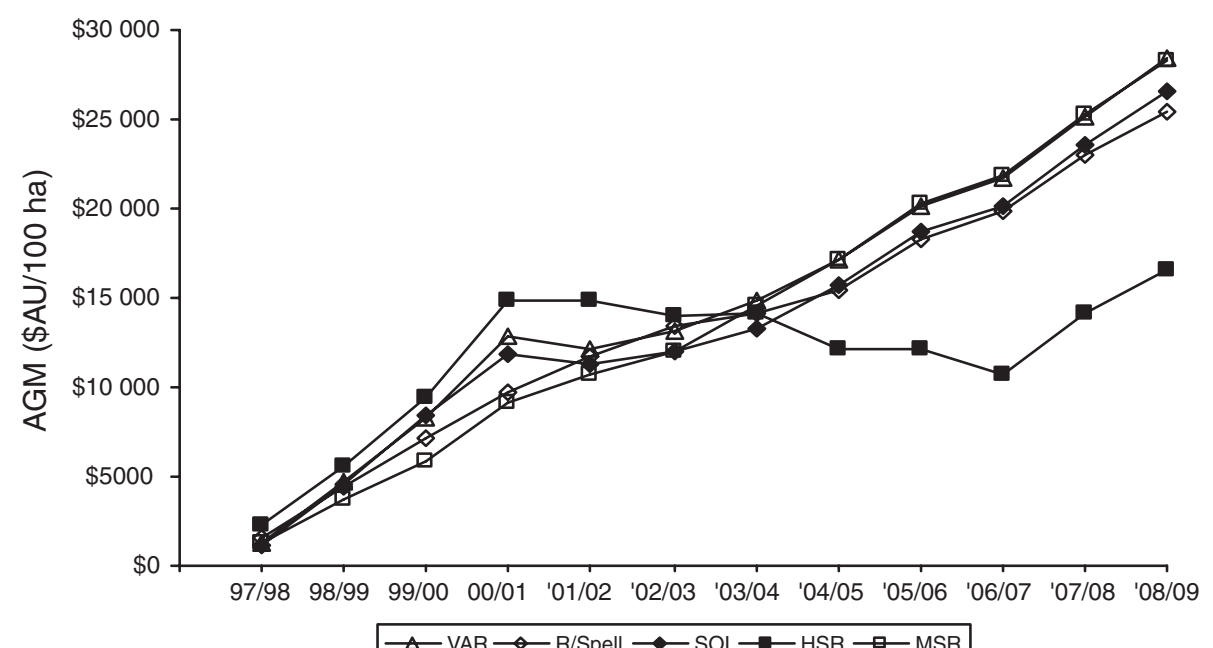

Fig. 5. Accumulated gross margin (AGM) per 100 ha, with interest compounded at $7.5 \%$ for the variable (VAR), rotational spell (R/Spell), southern oscillation index-variable (SOI), heavy stocking rate (HSR) and moderate stocking rate (MSR) strategies from 1997-98 to 2008-09. See text for details.

Net present value

In all NPV comparisons, the most profitable strategy over the 12 years was either the VAR or the MSR, followed relatively closely by the SOI and R/Spell strategies (Table 2). At all discount by interest rate combinations, the HSR was by far the least profitable strategy. In general, the relative profitability of the HSR declined 
Table 2. Net present value and annualised net present value after 12 years for five grazing strategies at the Wambiana grazing trial for interest and discount rates of $5,7.5$ and $10 \%$

HSR, heavy stocking rate; MSR, moderate stocking rate; R/Spell, rotational spelling; SOI, southern oscillation index-variable; VAR, variable

\begin{tabular}{lccc}
\hline $\begin{array}{l}\text { Grazing } \\
\text { strategy }\end{array}$ & $5 \%$ & $\begin{array}{l}\text { Rate } \\
7.5 \%\end{array}$ & $10 \%$ \\
\hline & Net present value & $(\$ / 100$ ha $)$ & \\
VAR & $\$ 15143$ & $\$ 11962$ & $\$ 9418$ \\
R/Spell & $\$ 13363$ & $\$ 10665$ & $\$ 8516$ \\
SOI & $\$ 14100$ & $\$ 11167$ & $\$ 8834$ \\
HSR & $\$ 9378$ & $\$ 6930$ & $\$ 5021$ \\
MSR & $\$ 14738$ & $\$ 11873$ & $\$ 9613$ \\
& Annualised net present value $(\$ / 100$ ha) & \\
VAR & $\$ 1709$ & $\$ 1546$ & $\$ 1382$ \\
R/Spell & $\$ 1508$ & $\$ 1379$ & $\$ 1250$ \\
SOI & $\$ 1591$ & $\$ 1444$ & $\$ 1297$ \\
HSR & $\$ 1058$ & $\$ 896$ & $\$ 737$ \\
MSR & $\$ 1663$ & $\$ 1535$ & $\$ 1411$ \\
\hline
\end{tabular}

as the interest rate on livestock capital and discount rate increased (Table 2).

In terms of annualised NPV, treatments performed in a similar order (Table 2). For example, at an interest and discount rate of $7.5 \%$, annualised NPV was highest for the VAR ( $\$ 1546 / 100$ ha) and the MSR ( $\$ 1535 / 100$ ha), followed by the SOI $(\$ 1444 / 100$ ha) and the R/Spell (\$1379/100 ha), but by far the lowest for the HSR (\$896/100 ha).

\section{Marginal analysis of high v. low stocking rates}

There was a clear financial advantage to the HSR in the first 4 years, with estimated margins of $\sim \$ 156 / 100$ ha per extra AE above those run in the MSR (Fig. 6). The advent of drier years in 2001-02, however, saw a sharp drop in marginal returns with estimated losses of about $-\$ 200 / 100$ ha for each extra
AE. These negative margins continued and averaged about $-\$ 280 / 100$ ha over the next 3 years, before dropping even further to $-\$ 1100 / 100$ ha per extra AE in 2006-07. Nevertheless, with better rainfall, margins rebounded sharply to about \$260/100 ha in 2007-08 and \$90/100ha in 2008-09 for each extra AE (Fig. 6).

\section{Sensitivity of marginal analysis to different interest rates and price differentials}

Averaged over all years, heavy stocking resulted in a negative margin for each extra $\mathrm{AE}$ added over those in the MSR, i.e. there was no financial advantage to running extra animals over and above those in the MSR (Fig. 2). Even at a $\% \%$ interest and no price premium for better-condition animals, each extra AE in the HSR above those in the MSR diminished the potential total GM by about $\$ 70 / 100$ ha. These negative margins increased as interest rates rose and the market price differential for better-condition animals widened. In dry years, margins per extra AE were also always negative, irrespective of interest rate or price differential. The only conditions where stocking rates above those in the MSR paid were in wet years, when (1) interest rates were $<7.5 \%$ and the price differential for better-condition cattle was $<\$ 0.06 / \mathrm{kg}$ or, (2) when interest rates were zero and the price differential was $\leq \$ 0.10 / \mathrm{kg}$.

These marginal relationships may obviously shift in future, due to changes in pasture composition and productive capacity. For example, with a change to an annual dominated pasture, running extra stock above those in the MSR in dry years may become even more unprofitable because of the poorer rainfall-use efficiency of such landscapes. Conversely, in very wet years, the relationships might shift upwards, i.e. carrying extra stock becomes more profitable because of the higher forage quality of annual dominated pastures (Ash and McIvor 1995).

\section{Discussion}

These results challenge the assertion that sustainable management is not profitable and the perception that "more

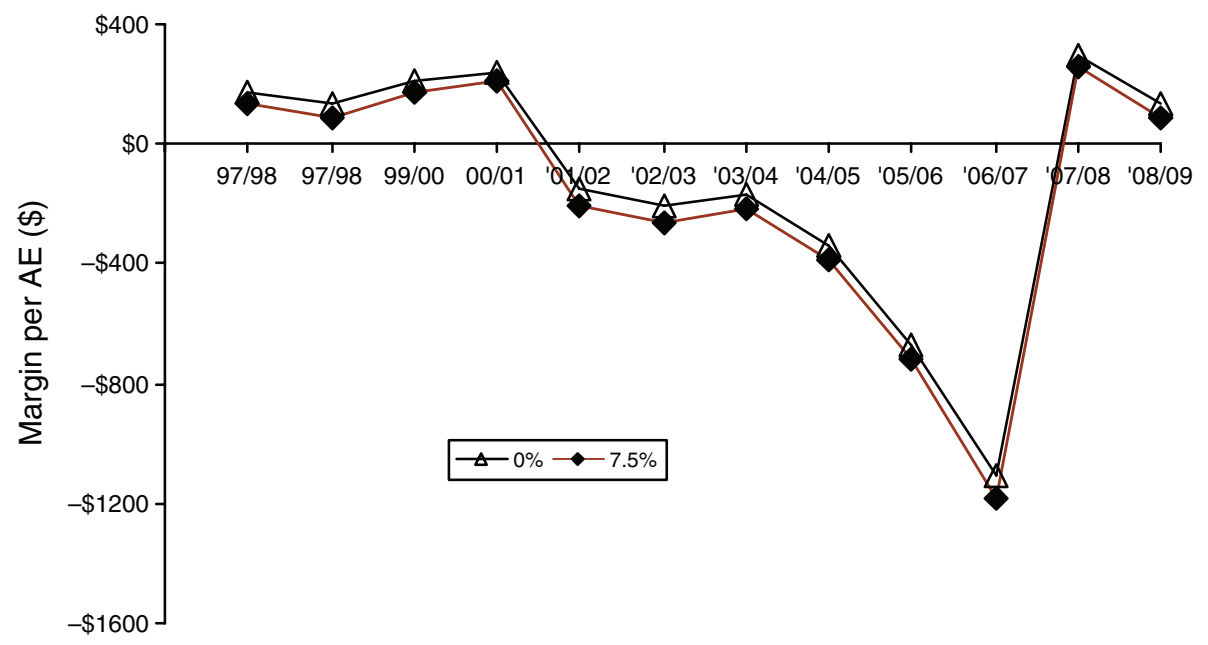

Fig. 6. Marginal return per extra animal equivalent (AE) per 100 ha from 1997-98 to $2008-09$ for heavy $v$. moderate stocking at $0 \%$ and $7.5 \%$ interest rates on livestock capital. 
cattle equal more money' (Stockwell et al. 1991). They provide the first long-term empirical evidence to show that recommended grazing strategies such as moderate or variable stocking can be just as, if not considerably more, profitable than heavy stocking. Profitability in the HSR after 12 years was not only the lowest compared with other strategies, income variability and the risk of incurring a negative GM were far greater. GMs in the HSR were only positive in wetter years when drought feeding was not required and price penalties for poor-condition animals were not incurred.

Initially, the HSR and the heavily stocked VAR and SOI strategies had higher GMs than the more lightly stocked MSR and $\mathrm{R} /$ Spell. Although individual animal production was lower and interest costs far higher in the former heavier-stocked strategies, total GM was boosted by the much greater production per area (O'Reagain et al. 2009). Good rainfall in these years allowed heavy stocking without incurring drought feeding costs or a price penalty for reduced animal condition. This suggests that heavy stocking can, initially at least, be very profitable under certain conditions. However, this period was exceptional in terms of both rainfall and the unbroken sequence of these wetter years. This initial profitability was also undoubtedly subsidised by the relatively good starting pasture condition and its delayed response to the grazing treatments (O'Reagain et al. 2008). Simulations run with data from southern Queensland (MacLeod et al. 2004) yielded similar results, with GMs increasing with stocking rate on good- (State 1) but not poorer-condition (States 2 or 3) pastures.

With the inevitable drier years, however, GMs of the heavierstocked strategies plummeted due to price penalties for poorer animal condition, a relatively large drop in beef production/area (O'Reagain et al. 2009) and the ongoing high interest costs on livestock capital (Table 1). As the dry years continued, HSR profitability was further eroded by the drought feeding costs (Table 1) required to maintain high stocking rates, giving negative GMs for the next 5 years (Fig. 4).

The HSR (at a reduced stocking rate) returned to positive GMs only in later years when above-average, well distributed rainfall gave exceptionally good animal performance on the resultant short, green grass in this strategy (O'Reagain and Bushell 2008). Given the greater relative frequency of average and belowaverage rainfall years (Clewett et al. 2003), it is unlikely the longer-term profitability of the HSR will ever fully recover. Animal production and GMs are rather likely to decline further in future dry years due to the significantly lower density of perennial grasses in this treatment (O'Reagain and Bushell 2008).

While the GM of the MSR appeared relatively modest in the early good seasons, this GM was largely sustained through the dry years, ensuring a positive GM in 11 of the 12 years. This reflected the relatively low variable costs, particularly the avoidance of drought feeding, and lower interest costs on livestock capital. Good individual animal performance in the MSR also increased product value through condition- and weightbased market premiums (O'Reagain et al. 2009). This supports the view that profitability under moderate stocking is favoured by price premiums and lower costs (e.g. Wilson and Macleod 1991; Landsberg et al. 1998).

The SOI and VAR strategies also had a substantially negative GM in the first dry year (Fig. 4). But in contrast to the HSR, cutting stocking rates in response to declining forage availability (VAR) and deteriorating seasonal climate forecasts (SOI) avoided the expense of drought feeding and substantially reduced interest costs. Lower stocking rates also improved individual animal production and product value (O'Reagain et al. 2009), allowing a return to positive GMs that were maintained through later, dry years. Varying stocking rates with changing seasonal conditions thus ensured that the VAR and SOI were far more profitable over the longer term than constant heavy stocking.

The forced reduction in stocking rates in the HSR in May 2005 might also have been expected to reduce costs and improve animal performance, allowing GMs to recover. However, profitability continued to be adversely affected by drought feeding costs, price penalties and reduced production per unit area, despite a stocking rate only about a third heavier than the MSR. GMs were also probably undermined by the decline in land condition observed in this strategy (O'Reagain and Bushell 2008).

Despite the positive GMs in 2007-08 and 2008-09, overall profitability in the HSR after 12 years was still far lower than the other strategies, particularly the VAR and MSR (Table 2). If these results are extrapolated upwards to a 20000 -ha property, at an interest rate of $7.5 \%$ over 12 years, a manager applying moderate stocking would have made an extra $\$ 2.5$ million in AGM or $\$ 988600$ in NPV compared with heavy stocking. This is obviously a very simplistic analysis, sensitive to assumptions about interest rates on livestock capital but indicates the potential magnitude of property-level benefits that might occur with more sustainable grazing management.

In marked contrast to the present results, profitability was greatest at the heaviest stocking rate in a 13-year grazing trial in central Queensland (Burrows et al.2010). Aside from differences in rainfall, soils, pasture composition and grazing resilience between the study areas, this discrepancy may be attributed to two main factors. First, in contrast to the present study where only the HSR received (and required) drought feeding, in dry years Burrows et al. (2010) provided drought feeding to all treatments irrespective of stocking rate. Second, no price premium was given for animal condition, with animals in the optimum weight ranges receiving only an extra $\$ 0.04 / \mathrm{kg}$ (Burrows et al. 2010). This is far lower than the $\$ 0.20 / \mathrm{kg}$ premium given to 'good-condition steers' in our economic analysis. Both of these factors would have removed or minimised the economic advantages that normally accrue to lighter or more moderate stocking rates through lower variable costs and superior product prices.

In the present study, it is significant that varying stocking rates in response to seasonal conditions was no more profitable than simply stocking at long-term carrying capacity. Indeed, based on inter-annual variability in GM, the SOI and VAR strategies achieved a similar outcome to moderate stocking but at a far greater level of risk. Although high stocking rates were initially financially advantageous, this was largely negated by losses incurred by reduced animal performance and forced sales at the beginning of the dry years.

Importantly, the high stocking rates in the variable strategies leading into the dry years also significantly damaged pasture condition. Despite significant recovery in later years, in 2009 the density of perennial grasses in the SOI and VAR was still lower 
than in the MSR and R/Spell (O'Reagain 2009). A major risk of variable stocking is thus that of being overstocked running into dry years, potentially leading to overgrazing, financial loss and resource degradation. As noted by Higgins et al. (2007), while variable or opportunistic strategies are 'intuitively appealing', they are not necessarily optimal relative to more conservative strategies such as constant moderate stocking.

The profitability of the VAR and SOI were possibly unfairly penalised by two factors. First, animal performance in both strategies was particularly poor in 2001-02 due to the combination of heavy stocking and low-quality, dry season forage (O'Reagain et al. 2009), a problem that might have been avoided with urea supplementation. Second, the heavy stocking rates applied in the early wet years were probably excessive and, as indicated, had an ongoing adverse effect on pasture condition and, possibly, animal production (O'Reagain et al. 2008). A risk-averse variable strategy with more conservative increases in stocking rate in wet years, coupled with sharper reductions in drier years, might avoid these problems and still increase profitability relative to constant moderate stocking.

The SOI strategy was also penalised by the sale of poorcondition animals at a net loss in November 2001 in the late dry season. Again, with urea supplementation, these cattle may have maintained weight better, possibly reducing the financial loss. Nevertheless, the issue of late-dry season (November) stocking rate adjustments highlights the fact that the current 3-month leadtime for SOI forecasts (Stone and de Hoedt 2000) limits its utility as a tool for managing climate variability.

While not advocating an extreme 'trader' strategy involving major fluctuations in stocking rate (Foran and Stafford-Smith 1991), the performance of both variable strategies could be improved with better guidelines for adjusting stock numbers with changing conditions. Although decision tools such as Stocktake (Aisthorpe et al. 2004) for forage budgeting and BREEDCOW (Holmes 2006) for herd dynamics are available, significant practical problems remain in implementing variable stocking with breeding animals (e.g. Diaz-Solis et al. 2009), particularly on extensive properties (Smith 2000).

The slightly lower profitability of the R/Spell relative to the MSR, VAR and SOI is unexpected; light-moderate stocking with wet season spelling should improve pasture condition (Ash et al. 2001), presumably increasing animal production and profitability. As indicated, the R/Spell was severely compromised by the 2001 fire, the subsequent drought and the forced sale of poor-condition animals. Despite this, the R/Spell was still far more profitable than the HSR. A key factor in the recovery of the $\mathrm{R} / \mathrm{Spell}$ was the 2003 reduction in stocking rates which, despite the short-term drop in GM, allowed reasonable animal performance and substantial pasture recovery in later years (O'Reagain et al. 2008).

In any economic analysis, the underlying assumptions obviously significantly affect the final outcome. The present analysis was very sensitive to interest rate assumptions on livestock capital; lower interest rates improved profitability in all strategies and, in particular, reduced the number of years at which the HSR recorded a loss. That aside, lowering interest rates from $7.5 \%$ to $5 \%$ had little effect on the relative performance of the different strategies. Irrespective of the interest rate, the key point is that all of the more 'sustainable' strategies were at the very worst as, if not considerably more, profitable than heavy stocking.

The choice of discount rate in NPV analyses is also crucial and identifying the most appropriate rate is problematic (Campbell et al. 2006). In the present study, the relative profitability of the HSR improved as discount rate increased, reflecting the initial good seasons and the time taken for the effects of heavy stocking on pasture condition to emerge. The sequence of profit and loss is also important in any NPV analysis (Campbell et al. 2006); again, the early gains of the VAR in the initial wet years probably account for it having a slightly greater NPV than the MSR.

Assumptions on livestock value are also critical. First, the condition-based market premium undoubtedly favoured treatments with good individual animal performance, such as moderate stocking (O'Reagain et al. 2009). This premium is a reality for meatworks cattle, but is probably of lesser importance for the finishing market, and of little or no importance for the liveexport cattle market. Second, the purchase and sale price of animals has a major impact on profitability. In particular, the fall in stock prices with declining rainfall, followed by a rebound at the end of drought (e.g. Diaz-Solis et al. 2009), would profoundly affect the profitability of any variable stocking strategy.

Importantly, the economic value of the observed differences in land condition between strategies (O'Reagain and Bushell 2008) were not included in the present analysis. Any land condition decline would reduce future profitability via lower carrying capacity, reduced animal performance in most years and the increased probability of feed deficits. The direct costs of restoring condition are also substantial (MacLeod and McIvor 2008; Teague et al. 2009). Other indirect but important environmental costs are the reduction in ecosystem services, including declines in biodiversity, water quality and soil carbon sequestration (e.g. Liebig et al. 2010).

Inclusion of these costs in the analysis would reduce the relative profitability of the HSR even further. Similarly, accounting for the slightly better land condition in the MSR and R/Spell (O'Reagain and Bushell 2008) would also improve their profitability relative to the VAR and the SOI strategies.

Further limitations of the present study must also be recognised. First, the trial period of 12 years is relatively short compared with longer-term climate variation and the rates of change in vegetation and ecosystem function. Given a different sequence of rainfall years, the relative profitability of the different strategies might also have been different. The VAR and SOI, for example, might have performed relatively poorly if the sequence of good and poor years had been more disjointed than those encountered.

Second, the work was conducted with non-reproductive animals and conventional wisdom is that breeder performance is less sensitive to stocking rate than steers (Ash and StaffordSmith 1996; Smith 2000). Theoretically, there is no a priori reason why strategies such as moderate stocking that are sustainable, profitable and give good animal production should not do the same with breeders. Nevertheless, with a majority of northern Queensland properties having large breeder herds (Bortolussi et al. 2005a), it will be critical to test how the present strategies affect the profitability of such operations. 
An important next step will be to investigate how these different grazing strategies affect enterprise-level economic performance and land condition using linked biophysical and economic models (e.g. MacLeod et al. 2004). Long-term simulations need to be run with breeding animals and steers at the property level under a range of market price, debt level and rainfall sequence scenarios (e.g. Stafford-Smith et al. 2000). Property case studies with participating producers in different areas (e.g. Buxton and Stafford-Smith 1996) would also provide strong evidence on the relative benefits of sustainable grazing strategies and assist in adoption.

\section{Management implications}

The present analysis indicates that contrary to conventional wisdom, heavy stocking rates are likely to be uneconomic in the medium to long term, with profitability eroded by high costs and reduced product value in most years. Moderate stocking at long-term carrying capacity is likely to be more profitable because of lower costs, increased product value and, probably, improved management flexibility. Rotational spelling with light to moderate stocking rates will also be more profitable than heavy stocking and, in the longer term, is likely to result in the best land condition. Varying stock numbers based on forage availability and, if appropriate, seasonal climate forecasts, will also be more profitable than heavy stocking because drought feeding costs are largely avoided and product value is maintained in drier years at low stocking rates. However, the management expertise required, as well as the associated economic and environmental risks, are likely to be higher than under constant moderate stocking. In summary, constant heavy stocking will be by far the least profitable of all stocking strategies in a variable climate. Incorporating the direct costs of declining resource condition, as well as any indirect societal costs via off-site impacts, further reinforces the case against this strategy.

\section{Acknowledgements}

We are grateful to the Lyons family of 'Wambiana' and the Wambiana Grazier Advisory Committee for their continued interest, guidance and support in running the trial. Trial establishment was funded via the Australian Government's Drought Regional Initiative. Funding support for the project has been provided by Meat and Livestock Australia, the Natural Heritage Trust, the Great Barrier Reef Marine Park Authority and the CRC for Tropical Savanna Management. Bob Shepherd, Geoff Fordyce, Angela Reid, Alan Laing, Joe Rolfe and other DEEDI and CSIRO colleagues provided valuable advice and support. Richard Allen, Colin Bredden, Peter Fry, Dave Smith and Peter Allen assisted with the collection of field data. We thank Fred Chudleigh, Megan Star and Peter Donaghy and two anonymous referees for valuable comments on earlier versions of this paper.

\section{References}

Aisthorpe J, Paton C, Timmers P (2004) 'Stocktake: balancing supply and demand.' (Queensland Department of Primary Industries and Fisheries: Brisbane)

Anonymous (2008a) 'Guideline to over-the-hooks trading of livestock.' (AUS-Meat Limited: Brisbane) Available at http://www.ausmeat.com. au/industry-standards/over-the-hooks-trading.aspx [Verified 8 February 2011]
Anonymous (2008b) 'Rainfall probabilities based on phases of the southern oscillation index.' (Environmental Protection Agency, The Queensland Climate Change Centre of Excellence: Brisbane) Available at http://www. longpaddock.qld.gov.au/SeasonalClimateOutlook/RainfallProbability/ index.html [Verified 8 February 2011]

Ash AJ, McIvor JG (1995) Land condition in the tropical tallgrass pasture lands. 2. Effects on herbage quality and nutrient uptake. The Rangeland Journal 17, 86-98. doi:10.1071/RJ9950086

Ash AJ, Stafford-Smith DM (1996) Evaluating stocking rate impacts in rangelands: animals don't practice what we preach. The Rangeland Journal 18, 216-243. doi:10.1071/RJ9960216

Ash A, O'Reagain PJ, McKeon G, Stafford Smith DM (2000) Managing climate variability in grazing enterprises: a case study of Dalrymple Shire, north-eastern Australia. In 'Applications of seasonal climate forecasting in agricultural and natural ecosystems: the Australian experience'. (Eds GL Hammer, N Nicholls, C Mitchell) pp. 253-270. (Kluwer Academic Publishers: Dordrecht, The Netherlands)

Ash A, Corfield JP, Ksiksi T (2001) 'The Ecograze Project: developing guidelines to better manage grazing country.' (CSIRO: Townsville, Qld)

Bortolussi G, McIvor JG, Hodgkinson JJ, Coffey SG, Holmes CR (2005a) The northern Australian beef industry, a snapshot. 1. Regional enterprise activity and structure. Australian Journal of Experimental Agriculture 45, 1057-1073. doi:10.1071/EA03096

Bortolussi G, McIvor JG, Hodgkinson JJ, Coffey SG, Holmes CR (2005b) The northern Australian beef industry, a snapshot. 2. Breeding herd performance and management. Australian Journal of Experimental Agriculture 45, 1075-1091. doi:10.1071/EA03097

Briske DD, Derner JD, Brown JR, Fuhlendorf SD, Teague WR, Havstad KM, Gillen RL, Ash AJ, Willms WD (2008) Rotational grazing on rangelands: reconciliation of perception and experimental evidence. Rangeland Ecology and Management 61, 3-17. doi:10.2111/06-159R.1

Burrows WH, Orr DM, Hendricksen RE, Rutherford MT, Myles DJ, Back PV, Gowen R (2010) Impacts of grazing management options on pasture and animal productivity in a Heteropogon contortus (black speargrass) pasture in central Queensland. 4. Animal production. Animal Production Science 50, 284-292. doi:10.1071/AN09145

Buxton R, Stafford-Smith M (1996) Managing drought in Australia's rangelands: four weddings and a funeral. The Rangeland Journal 18, 292-308. doi:10.1071/RJ9960292

Campbell BM, Gordon IJ, Luckert MK, Petheram L, Vetter S (2006) In search of optimal stocking regimes in semi-arid grazing lands: one size does not fit all. Ecological Economics 60, 75-85. doi:10.1016/j.ecolecon.2006. 05.010

Chilcott CR, McCallum BS, Quirk MF, Paton CJ (2003) Grazing land management education package notes - Burdekin. Meat and Livestock Australia Ltd, Sydney.

Chisholm A, Dillon J (1966) 'Discounting and other interest rate procedures in farm management.' (Department of Farm Management, University of New England: Armidale, NSW)

Clewett JF, Clarkson NM, George DA, Ooi SH, Owens DT, Partridge IJ, Simpson GB (2003) 'Rainman Streamflow version 4.3: a comprehensive climate and streamflow analysis package on $\mathrm{CD}$ to assess seasonal forecasts and manage climate risk.' (Department of Primary Industries: Brisbane)

Danckwerts JE, O'Reagain PJ, O'Connor TG (1993) Range management in a changing environment: a southern African perspective. The Rangeland Journal 15, 133-144.

De Corte M, Cannon M, Barry E, Bright J, Scanlan J (1991) ‘Land degradation in the Dalrymple Shire: a preliminary assessment.' (CSIRO, Davies Laboratory, Townsville, Qld.)

Diaz-Solis H, Grant W, Kothmann M, Teague W, Diaz-Garcia J (2009) Adaptive management of stocking rates to reduce effects of drought on cow-calf production systems in semi-arid rangelands. Agricultural Systems 100, 43-50. doi:10.1016/j.agsy.2008.12.007 
Ebersohn JP (1973) Environmental limitations and their role in the stability of low rainfall grazing lands and grasslands: a case history and viewpoint. In 'III World conference on animal production, short contributions, pre-conference, vol 1', University of Melbourne. p. 2(d-6).

Eyles AG, Cameron DG, Hacker JB (1985) 'Pasture research in northern Australia - its history, achievements and future emphasis.' (Courier-Mail Printing Service: Brisbane)

Foran BD, Stafford-Smith DM (1991) Risk, biology and drought management strategies for cattle in central Australia. Environmental Management 33, 17-33. doi:10.1016/S0301-4797(05)80045-3

Furnas M (2003) 'Catchments and corals: terrestrial runoff to the Great Barrier Reef.' (Australian Institute of Marine Science: Townsville, Qld)

Gillard P (1979) Improvement of native pastures with Townsville stylo in the dry tropics of sub-coastal northern Queensland. Australian Journal of Experimental Animal Husbandry 19, 325-336. doi:10.1071/EA9790325

Higgins SI, Kantelhardt J, Scheiter S, Boerner J (2007) Sustainable management of extensively managed savanna rangelands. Ecological Economics 62, 102-114. doi:10.1016/j.ecolecon.2006.05.019

Hinton AW (1993) 'Economics of beef production in the Dalrymple Shire.' (Department of Primary Industries QO93005: Brisbane)

Holmes WE (2006) 'Breedcow and Dynama Herd budgeting software package.' (Queensland Department of Primary Industries: Townsville, Qld)

Isbell RF (1996) 'The Australian soil classification.' (CSIRO Publishing: Melbourne)

Johnston PW, McKeon GM, Buxton R, Coban DH, Day KA, Hall WB, Scanlan JC (2000) Managing climatic variability in Queensland's grazing lands - new approaches. In 'Applications of seasonal climate forecasting in agricultural and natural ecosystems: the Australian experience'. (Eds GL Hammer, N Nicholls, C Mitchell) pp. 197-226. (Kluwer Academic Publishers: Dordrecht, The Netherlands)

Karfs RA, Abbott BN, Scarth PF, Wallace JF (2009) Land condition monitoring information for reef catchments: a new era. The Rangeland Journal 31, 69-86.

Landsberg RG, Ash AJ, Shepherd RK, McKeon GM (1998) Learning from history to survive in the future: management evolution on Trafalgar Station, north-east Queensland. The Rangeland Journal 20, 104-118. doi:10.1071/RJ9980104

Lawrence DM, Graham TWG, Clark RA (1994) Sustainable grazing management: grazier's perspectives and implications for pasture management in the Maranoa region, South Queensland. Tropical Grasslands 28, 24-31.

Liebig MA, Gross JR, Kronburg SL, Phillips RL, Hanson JD (2010) Grazing management contributions to net global warming potential: a long-term evaluation in the Northen Great Plains. Journal of Environmental Quality 39, 799-809. doi:10.2134/jeq2009.0272

MacLeod ND, McIntyre S (1997) Stocking rate impacts on the production and economic performance of steers grazing black speargrass pastures. The Rangeland Journal 19, 174-189. doi:10.1071/RJ9970174

MacLeod ND, McIvor JG (2008) Quantifying production-environment tradeoffs for grazing land management - A case example from the Australian rangelands. Ecological Economics 65, 488-497. doi:10.1016/ j.ecolecon.2007.07.013

MacLeod ND, Ash AJ, McIvor JG (2004) An economic assessment of the impact of grazing land condition on livestock performance in tropical woodlands. The Rangeland Journal 26, 49-71. doi:10.1071/ RJ04004

Mann TH (1993) Flexibility - the key to managing a northern beef property. In 'Proceedings XVII International Grasslands Congress'. 18-21 February, Rockhampton, Australia. pp. 1961-1964.

McIvor JG, Gardner CJ (1995) Pasture management in semi-arid tropical woodlands: effects on herbage yields and botanical composition. Australian Journal of Experimental Agriculture 35, 705-715. doi:10.1071/EA9950705
McKeon G, Day KA, Howden SM, Mott JJ, Orr DM, Scattini WJ, Weston EJ (1990) Northern Australian savannas: management for pastoral production. Journal of Biogeography 17, 355-372. doi:10.2307/ 2845365

McKeon G, Howden SM, Abel NO, King JM (1993) Climate change adapting tropical and subtropical grasslands. In 'Proceedings XVII International Grassland Congress, 8-21 February 1993', Palmerston North, New Zealand. pp. 1181-1190.

McKeon G, Hall W, Crimp SJ, Howden SM, Stone RC, Jones DA (1998) Climate change in Queensland's grazing lands. I. Approaches and climatic trends. The Rangeland Journal 20, 151-173. doi:10.1071/ RJ9980151

McKeon G, Ash A, Hall W, Strafford-Smith M (2000) Simulation of grazing strategies for beef production in north-east Queensland. In 'Applications of seasonal climate forecasting in agricultural and natural ecosystems, the Australian experience'. (Eds GL Hammer, N Nicholls, C Mitchell) pp. 227-252. (Kluwer Academic Publishers: Dordrecht, The Netherlands)

McKeon G, Cunningham GM, Hall WB, Henry BK, Owens JS, Stone GS, Wilcox DG (2004) Degradation and recovery episodes in Australia's rangelands: an anthology. In 'Pasture degradation and recovery in Australia's rangelands: learning from history'. (Eds G McKeon, WB Hall, BK Henry, GS Stone, IW Watson) pp. 87-172. (Queensland Department of Natural Resources, Mines and Energy: Brisbane)

McKeon GM, Stone GS, Syktus JI, Carter JO, Flood NR, Ahrens DG, Bruget DN, Chilcott CR, Cobon DH, Cowley RA, Crimp SJ, Fraser GW, Howden SM, Johnston PW, Ryan JG, Stokes CJ, Day KA (2009) Climate change impacts on northern Australian rangeland livestock carrying capacity: a review of issues. The Rangeland Journal 31, 1-29.

Muller B, Frank K, Wissel C (2007) Relevance of rest periods in nonequilibrium rangeland systems - a modelling analysis. Agricultural Systems 92, 295-317. doi:10.1016/j.agsy.2006.03.010

Nicholson C, Barr N, Kentish A, Dowling PM, McCormick LH, Palmer M, Simpson IH, Simpson K, Walsh J (2003) A research-extension model for encouraging the adoption of productive and sustainable practice in high rainfall grazing areas. Australian Journal of Experimental Agriculture 43, 685-694. doi:10.1071/EA02212

O'Meagher B (2003) Economic aspects of drought and drought policy. In 'Beyond drought: people, policy and perspectives'. (Eds L Botterill, M Fisher) pp. 109-130. (CSIRO Publishing: Melbourne)

O'Reagain PJ (2009) Final report: B.NBP.0379. Wambiana grazing trial extension: testing and developing grazing principles and management guidelines for the seasonably variable tropical savannas. Meat and Livestock Australia, Sydney.

O'Reagain PJ, Bushell JJ (2008) Sustainable and profitable grazing management in a highly variable environment - evidence and insights from a long term grazing trial in northern Australia. In 'Multifunctional grasslands in a changing world, proceedings of the XXI international grassland congress - VII international rangeland congress', Hohhot, Inner Mongolia. pp. 14-19. (Guangdong People's Publishing House: Beijing)

O'Reagain P, McKeon G, Day K, Ash A (2003) Managing for temporal variability in extensive rangelands - a perspective from northern Australia. In 'Proceedings of the VII th international rangelands congress', Durban, South Africa, July 2003. (Eds N Allsopp, SJ Milton, KP Kirkman, GIH Kerley, CR Hurt, CJ Brown) pp. 799-809. (CD-ROM)

O'Reagain PJ, Brodie J, Fraser G, Bushell JJ, Holloway CH, Faithful JW, Haynes D (2005) Nutrient loss and water quality under extensive grazing in the upper Burdekin river catchment, North Queensland. Marine Pollution Bulletin 51, 37-50. doi:10.1016/j.marpolbul.2004.10.023

O'Reagain PJ, Bushell JJ, Holloway CH (2008) Final report: B.NBP.0379. Testing and developing grazing principles and management guidelines for the seasonably variable tropical savannas. Meat and Livestock Australia, Sydney. 
O’Reagain PJ, Bushell JJ, Holloway CH, Reid A (2009) Managing for rainfall variability: effect of grazing strategy on cattle production in a dry tropical savanna. Animal Production Science 49, 85-99. doi:10.1071/EA07187

Pannell DJ, Marshall GR, Barr N, Curtis A, Vanclay F, Wilkinson R (2006) Understanding and promoting adoption of conservation practices by rural landholders. Australian Journal of Experimental Agriculture 46, 1407-1424. doi:10.1071/EA05037

Perry RA (1977) The evaluation and exploitation of semi-arid lands: Australian experience. Philosophical Transactions of the Royal Society of London. Series B, Biological Sciences 278, 493-505. doi:10.1098/ rstb.1977.0057

Pressland AJ, Mills JR, Cummins VG (1988) Landscape degradation in native pasture. In 'Native pastures in Queensland: the resources and their management'. (Eds B Burrows, J Scanlan, MT Rutherford) pp. 174-197. (Queensland Department of Primary Industries: Brisbane)

Scanlan JC, McKeon GM, Day KA, Mott JJ, Hinton AW (1994) Estimating safe carrying capacities in extensive cattle grazing properties within tropical semi-arid woodlands of north-eastern Australia. The Rangeland Journal 16, 64-76. doi:10.1071/RJ9940064

Sinden J, Thampapillai D (1995) 'Introduction to benefit cost analysis.' (Longman: Melbourne)

Smith D (2000) Northern stocking rate demonstration. Queensland Department of Primary Industries and Fisheries, unpublished report no. Promis \# 1480, Brisbane.

Stafford-Smith M, Buxton R, McKeon G, Ash A (2000) Seasonal climate forecasting and the management of rangelands: do production benefits translate into enterprise profits? In 'Applications of seasonal climate forecasting in agricultural and natural systems: the Australian experience'. (Eds GL Hammer, N Nicholls, C Mitchell) pp. 271-290. (Kluwer Academic Publishers: Dordrecht, The Netherlands)
Stockwell TGH, Smith PC, Stafford Smith DM, Hirst DJ (1991) Sustaining productive pastures in the tropics. 9. Managing cattle. Tropical Grasslands 25, 137-144.

Stone RC, de Hoedt G (2000) The development and delivery of current seasonal climate forecasting capabilities in Australia. In 'Applications of seasonal climate forecasting in agricultural and natural ecosystems'. (Eds GL Hammer, N Nicholls, C Mitchell) pp. 67-76. (Kluwer Academic Publishers: Dordrecht, The Netherlands)

Stone R, Hammer G, Marcussen T (1996) Prediction of global rainfall probabilities using phases of the southern oscillation index. Nature 384, 252-255. doi: $10.1038 / 384252 \mathrm{a} 0$

Teague W, Kreuter U, Grant W, Diaz-Solis H, Kothmann M (2009) Economic implications of maintaining rangeland ecosystem health in a semi-arid savanna. Ecological Economics 68, 1417-1429. doi:10.1016/j.ecolecon. 2008.10.014

Tothill JC, Gillies C (1992) 'The pasture lands of northern Australia. Their condition, productivity and sustainability.' (Tropical Grassland Society of Australia: Brisbane)

Wilson AD, Macleod ND (1991) Overgrazing - present or absent? Journal of Range Management 44, 475-482. doi:10.2307/4002748

Wilson A, Harrington GN, Beale IF (1984) Grazing management. In 'Management of Australia's rangelands'. (Eds GN Harrington, A Wilson, MD Young) pp. 129-139. (CSIRO: Melbourne)

Manuscript received 25 June 2010, accepted 17 January 2011 
Appendix 1. Animal husbandry actions and the strategies involved for cattle on the Wambiana grazing trial between 1997-98 and 2008-09 BEFV, bovine ephemeral fever vaccination; BOT, botulism vaccination; DS-urea, dry-season urea supplementation; HGP, hormone growth promotants; M8U, molasses and urea drought feeding; WS-P, wet-season P supplementation; WS, weaner supplement. Strategies involved indicated as follows: $\checkmark$, applied to all strategies; -, not applied to any strategies; HSR, applied to heavy stocking rate; SOI, applied to southern oscillation index; VAR, applied to variable stocking rate

\begin{tabular}{|c|c|c|c|c|c|c|c|c|c|c|c|c|}
\hline \multirow[t]{2}{*}{ Treatment } & \multicolumn{12}{|c|}{ Year } \\
\hline & 1997-98 & 1998-99 & 1999-2000 & $2000-01$ & $2001-02$ & $2002-03$ & 2003-04 & 2004-05 & 2005-06 & 2006-07 & $2007-08$ & 2008-09 \\
\hline HGP & - & - & - & - & - & - & - & $\checkmark$ & $\checkmark$ & $\checkmark$ & $\checkmark$ & $\checkmark$ \\
\hline DS-urea & - & - & - & - & - & $\checkmark$ & $\checkmark$ & $\checkmark$ & $\checkmark$ & $\checkmark$ & $\checkmark$ & $\checkmark$ \\
\hline WS-P & - & - & - & - & - & - & - & $\checkmark$ & $\checkmark$ & $\checkmark$ & $\checkmark$ & $\checkmark$ \\
\hline M8U & - & - & - & - & - & - & HSR & HSR & HSR & HSR & - & - \\
\hline BOT & $\checkmark$ & - & $\checkmark$ & $\checkmark$ & $\checkmark$ & $\checkmark$ & $\checkmark$ & $\checkmark$ & $\checkmark$ & $\checkmark$ & $\checkmark$ & $\checkmark$ \\
\hline BEFV & - & - & - & - & - & - & - & - & - & - & $\checkmark$ & $\checkmark$ \\
\hline WS & - & - & - & - & SOI/VAR/HSR & - & - & - & - & - & - & - \\
\hline
\end{tabular}

Appendix 2. Prices per kg (liveweight) from 1997-98 to 2008-09 used in the economic analysis for the five grazing strategies at the Wambiana grazing trial

HSR, heavy stocking rate; MSR, moderate stocking rate; R/Spell, rotational spelling; SOI, southern oscillation index-variable; VAR, variable

\begin{tabular}{|c|c|c|c|c|c|c|c|c|c|c|c|c|}
\hline \multirow{2}{*}{$\begin{array}{l}\text { Grazing } \\
\text { strategy }\end{array}$} & \multicolumn{12}{|c|}{ Price per kg liveweight $(\$ / \mathrm{kg})$} \\
\hline & 1997-98 & 1998-99 & $1999-2000$ & $2000-01$ & $2001-02$ & $2002-03$ & $2003-04$ & 2004-05 & $2005-06$ & $2006-07$ & $2007-08$ & 2008-09 \\
\hline VAR & $\$ 1.50$ & $\$ 1.50$ & $\$ 1.50$ & $\$ 1.30$ & $\$ 1.30$ & $\$ 1.50$ & $\$ 1.50$ & $\$ 1.50$ & $\$ 1.50$ & $\$ 1.50$ & $\$ 1.50$ & $\$ 1.50$ \\
\hline $\mathrm{R} / \mathrm{Spell}$ & $\$ 1.50$ & $\$ 1.50$ & $\$ 1.50$ & $\$ 1.30$ & $\$ 1.50$ & $\$ 1.50$ & $\$ 1.50$ & $\$ 1.30$ & $\$ 1.50$ & $\$ 1.50$ & $\$ 1.50$ & $\$ 1.50$ \\
\hline SOI & $\$ 1.50$ & $\$ 1.50$ & $\$ 1.50$ & $\$ 1.30$ & $\$ 1.50$ & $\$ 1.50$ & $\$ 1.50$ & $\$ 1.50$ & $\$ 1.50$ & $\$ 1.50$ & $\$ 1.50$ & $\$ 1.50$ \\
\hline HSR & $\$ 1.50$ & $\$ 1.50$ & $\$ 1.50$ & $\$ 1.50$ & $\$ 1.30$ & $\$ 1.30$ & $\$ 1.30$ & $\$ 1.30$ & $\$ 1.30$ & $\$ 1.30$ & $\$ 1.50$ & $\$ 1.50$ \\
\hline MSR & $\$ 1.50$ & $\$ 1.50$ & $\$ 1.50$ & $\$ 1.50$ & $\$ 1.50$ & $\$ 1.50$ & $\$ 1.50$ & $\$ 1.50$ & $\$ 1.50$ & $\$ 1.50$ & $\$ 1.50$ & $\$ 1.50$ \\
\hline
\end{tabular}

